\title{
Phthalanilic Acid with Biostimulatory Functions Affects Photosynthetic and Antioxidant Capacity and Improves Fruit Quality and Yield in Cowpea (Vigna unguiculata (L.) Walp.)
}

\author{
Ting Ma ${ }^{1}$, Qiong $\mathrm{Wu}^{1}{ }^{1}, \mathrm{Na} \mathrm{Liu}^{1}$, Rong Zhang ${ }^{2}$ and Zhiqing Ma ${ }^{1,3, *}$ \\ 1 College of Plant Protection, Northwest A\&F University, Xianyang 712100, China; \\ mating@nwafu.edu.cn (T.M.); qiongw999@163.com (Q.W.); nanalaaa@163.com (N.L.) \\ 2 Shaanxi Sunger Road Bio-Science Co., Ltd., Xi'an 710400, China; zhngrng@163.com \\ 3 Provincial Center for Bio-Pesticide Engineering, Xianyang 712100, China \\ * Correspondence: zhiqingma@nwsuaf.edu.cn; Tel./Fax: +86-(29)-8709-2122
}

\section{check for} updates

Citation: Ma, T.; Wu, Q.; Liu, N.; Zhang, R.; Ma, Z. Phthalanilic Acid with Biostimulatory Functions Affects Photosynthetic and Antioxidant Capacity and Improves Fruit Quality and Yield in Cowpea (Vigna unguiculata (L.) Walp.). Agriculture 2021, 11, 1082. https://doi.org/ 10.3390 /agriculture11111082

Academic Editor: Cinzia

Margherita Bertea

Received: 15 September 2021

Accepted: 26 October 2021

Published: 1 November 202

Publisher's Note: MDPI stays neutral with regard to jurisdictional claims in published maps and institutional affiliations.

Copyright: (C) 2021 by the authors. Licensee MDPI, Basel, Switzerland. This article is an open access article distributed under the terms and conditions of the Creative Commons Attribution (CC BY) license (https:// creativecommons.org/licenses/by/ $4.0 /)$

\begin{abstract}
The widespread application of biostimulants with a growing trend represents sustainable practices aimed at improving growth and yield and alleviating stresses in green agricultural system. Phthalanilic acid (PPA), with biostimulatory functions, has been increasingly applied to fruit and vegetable production. However, its specific biostimulatory effects on growth and development of cowpea (Vigna unguiculata) plants is still unclear. In this study, the regulatory function of foliar spraying PPA at the flowering timing in morphometric (length, width, single pod weight and yield), physiological (relative electrical conductivity), and biochemical (antioxidant enzymes activity, photosynthetic pigment, malondialdehyde, vitamin $C$, soluble protein, and soluble sugar content) parameters of cowpea plants were investigated. In general, PPA treatments exhibited higher antioxidant enzymes activities (with an increase of 11.89-51.62\% in POD), lower relative conductivity (with a decrease of 22.66-62.18\%), increased photosynthetic pigment levels and amounts of free proline (with an increase of $24.62-90.52 \%$ ), and decreased malondialdehyde. Furthermore, the length, width and weight of single pod, podding rate (with an increase of 19.64\%), vitamin C, soluble protein (with an increase of $18.75 \%$ ), and soluble sugar content were increased by $200 \mathrm{mg} \cdot \mathrm{L}^{-1} \mathrm{PPA}$. These data, together with an increased yield of $15.89 \%$, suggest that PPA positively regulates the growth and development, improving fruit quality and yield, especially at $200 \mathrm{mg} \cdot \mathrm{L}^{-1}$. This study indicates that PPA has biostimulatory effects in cowpea production and shows application prospect in field cultivation.
\end{abstract}

Keywords: biostimulants; photosynthetic characteristics; antioxidant activity; fruit

\section{Introduction}

Better fruit quality and higher yield are always the goals for agricultural production. However, abiotic stresses, such as drought, salinity, heat, and chill, severely threaten field cultivation. In recent years, the applications of biostimulants have become an effective strategy for the enhancement of sustainable practices to mitigate stresses and improve growth and yield by regulating plant physiological and biochemical processes in field green production [1-4]. In general, biostimulants, with multiple components, are categorized as silicon, protein hydrolysates, seaweed extracts, and humic substances [5-7]. Specifically, the stimulation on crop growth and development and is ascribed to peptides, algal polymers, and molecular inducing the production of phytohormones [8,9], antioxidants decreasing stresses [10,11], and plant growth regulators [12,13].

For standard biostimulants, the constituents are always complex and triggered effects are the synergy of the mixture; thus, the mechanism of action is unlikely to be completely exposed [1]. Apart from the mixture, some small molecules, showing biostimulatory effects, positively alert physiological and biochemical processes, including seed germination, root nodulation formation of legume crops, light utilization, crop nutrient absorption, 
and adverse stresses tolerance [14-18]. Triacontanol promoted growth, photosynthetic capacity [19], and functioned as an antioxidative agent through inhibiting peroxidative damage of cellular proteins and lipids [20]. Brassinolide application improved the drought tolerance in maize through modulation of enzymatic antioxidants and leaf gas exchange [21]. Similarly, abscisic acid (ABA) and brassinolide application promoted antioxidant activity in tall fescue under water stress [22]. In addition, exogenous application of glycinebetaine up-regulated photosynthetic capacity and antioxidase activities in salt-stressed maize plants [23].

Phthalanilic acid (PPA), as a crystalline amido acid, with melting point of $168^{\circ} \mathrm{C} \pm 1{ }^{\circ} \mathrm{C}$, which is soluble in anhydrous methanol, ethanol, acetone, and other organic solvents, was first developed by the Hungarian Neviki Institute of Chemical Industry in 1982 [23,24]. PPA promotes flower and fruit retention, significantly increasing the yield of apples, cherries and plums [25-28], and mitigate the unfavorable effect on crops [29]. PPA was used in fruit trees, corn, alfalfa, rape, sunflower, and some ornamental plants to promote higher yield and obtain more economic benefits [24,30]. Post-PPA applications enhanced stress resistance of capsicum in field trials, along with the promotion of chlorophyll content, and antioxidant enzyme activities, as well as increased yield, were observed in previous research [27]. In spite of positive regulations on capsicum and some plants, whether PPA has positive biostimulatory effects on other vegetables needs further research.

Cowpea (Vigna unguiculata L.), an important legume crop, is rich in protein and phenolic compounds, which is not only used as fresh vegetables but also as a dry grain to supplement the cereal-based diet for protein needs [31,32]. Compared to other vegetables, it grows well in the barren soil without needing an extra nitrogen application [33]. For all the above reasons, it is widely cultivated in throughout Southeast Asia, Africa, the southern United States, and Latin America, as well as in Mediterranean countries [34]. In modern cowpea production, substances with regulatory effects were introduced into field cultivation. Spraying exogenous IAA significantly decreased the number of flowers abscised from cowpea plants [35]; $\mathrm{GA}_{3}$ that was applied to cowpea also increased the yield [36]. However, there is no report about using PPA on cowpea by now.

In view of the above, this study systematically determined photosynthetic, antioxidant, nutrient, and other physiological and biochemical indexes to comprehensively assess the biostimulation effects of PPA on the growth, final yield, and fruit quality of cowpea plants. These results would provide guidance for its rational use in cowpea fields, as well as lay the foundation for the subsequent reveal of the biostimulatory mechanism.

\section{Material and Methods}

\subsection{Plants and Chemicals}

Cowpea (Vigna unguiculata L.) seeds were purchased from Yangling Agricultural High-Tech Development Co., Ltd., Yangling, China. 20\% PPA AS (Aqueous Solution) was provided by Shaanxi Sunger Road Bio-Science Co., Ltd., China. 0.0075\% Brassinolide AS was purchased from Chengdu New Sun Crop Science Co., Ltd., China. Other reagents, polyvinylpyrrolidone, riboflavin, bovine serum albumin, etc., were obtained from SigmaAldrich, St. Louis, MO, USA.

\subsection{Experimental Design}

A field trial was conducted from May to July 2016 at the Northwest A\&F University experimental base. The soil for field trials was Guanzhong soil with medium soil fertility. The ploughing layer $(10-20 \mathrm{~cm}$ in depth) contained $10.2 \mathrm{~g} / \mathrm{kg}$ of organic matter, $1.20 \mathrm{~g} / \mathrm{kg}$ of total nitrogen, $0.18 \mathrm{~g} / \mathrm{kg}$ of total phosphorus $\left(\mathrm{P}_{2} \mathrm{O}_{5}\right), 5.37 \mathrm{mg} / \mathrm{kg}$ of effective phosphorus $(p)$, and $150.0 \mathrm{mg} / \mathrm{kg}$ of quick-acting potassium. During the experimental periods, average daily maximum and minimum temperatures were $28^{\circ} \mathrm{C}$ and $16^{\circ} \mathrm{C}$, respectively. Cowpea seeds were sowed on 30 April at the rate of two seeds per hole, with the spacing of $35 \mathrm{~cm} \times 65 \mathrm{~cm}$. All treatments were arranged in a randomized complete block design with three replicates $\left(15 \mathrm{~m}^{2}\right.$ per replication), and ten plants with the similar growth trend 
were selected from each plot for assays. The experiment consisted of the following five treatments: the blank control, $0.075 \mathrm{mg} \cdot \mathrm{L}^{-1}$ brassinolide (PGR control), $133.3 \mathrm{mg} \cdot \mathrm{L}^{-1} \mathrm{PPA}$, $200.0 \mathrm{mg} \cdot \mathrm{L}^{-1} \mathrm{PPA}$, and $266.7 \mathrm{mg} \cdot \mathrm{L}^{-1} \mathrm{PPA}$. PPA and brassinolide were applied to cowpea seedlings by high volume spray during the seedling stage (3-4 true leaves; spray volume of $450 \mathrm{~kg} \cdot \mathrm{hm}^{-2}$ ) and the early flowering period (spray volume of $900 \mathrm{~kg} \cdot \mathrm{hm}^{-2}$ ). Ten plants with the same growth were selected from each plot, and the middle leaflets of compound leaves at the same position were used for experiments.

\subsection{Physiological and Biochemical Measurements}

The net photosynthetic rate (Pn), stomatal conductance (Gs), intercellular $\mathrm{CO}_{2}$ concentration $(\mathrm{Ci})$, and transpiration rate $(\mathrm{Tr})$ were determined by the portable photosynthesis system (LI-6400XT) with standard $6 \mathrm{~cm}^{2}$ leaf chamber and red-blue LED light source. At the seedlings (5-6 true leaves), full-bloom, and early podding stage, fully-expanded mature leaves (the upper third leaf) of cowpea were measured on sunny days, and results were collected from five randomly selected plants for each plot. In the course of measurement, saturating light intensity was kept at $1500 \mathrm{mmol} \cdot \mathrm{m}^{-2} \cdot \mathrm{s}^{-1}$, and three readings (1-min interval for each reading) were recorded averagely to make the measurement stability and precision [37]. Data were reported as the mean value of three replicates (five seedlings per replicate) for each treatment.

The chlorophyll content of the cowpea leaves was determined by previously described procedure [38], and the electrolyte leakage was assayed by the relative conductivity following the method of Ekmekci and Terzioglu [39]. The malonaldehyde (MDA) content was measured by the thiobarbituric acid (TBA) method [40]. Proline content was determined according to the method [41] and expressed as $\mu \mathrm{g} / \mathrm{g}$ dry weight. For estimation of antioxidant enzymes, the pretreatment of the sample was based on the methods of Xiong et al. (2016) [42]. Superoxide dismutase (SOD) activity was determined by measuring the inhibition of the photoreduction of nitro blue tetrazolium (NBT) at $560 \mathrm{~nm}$ [43]. Peroxidases (POD) was detected by testing the initial rate of guaiacol oxidation at $470 \mathrm{~nm}$ [43]. Catalase (CAT) activity was evaluated by assaying the initial rate of $\mathrm{H}_{2} \mathrm{O}_{2}$ decrease through measuring the absorbance change at $240 \mathrm{~nm}$ [43]. On the 3rd, 7th, 11th, 14th, and 21st day after the second PPA application, the upper third leaflets from the ten cowpea plants, which were randomly selected as the fixed point for each plot, were used for assays.

\subsection{Assessment of Fruit Quality and Yield}

\subsubsection{Fruit Quality}

The determination of pod length, width, and single pod weight was according to the method of Masuthi et al. (2010) [44]. Ten cowpea pods without difference on appearance and maturity were chosen randomly from each plot and then were broken by a homogenizer, with pulp for testing the content of soluble sugar, soluble protein, and vitamin C. Concentration of soluble sugar was determined by the anthrone colorimetric method, while the content of soluble protein was detected by the coomassie brilliant blue G-250 method [37]. The 2, 6-dichlorindophenol titration method was applied to assay vitamin C content [37].

\subsubsection{Podding Rate and Yield}

The podding rate was measured by the method [45]. Specifically, thirty flowers were marked for each plot, and then the number of pods was counted after two days. The flower numbers were marked three times during the entire flowering period, with data representing the mean of three statistics for per treatment. Overall yield was determined as the sum of cowpea weight for choosing commodity pods during the harvest period, and it was extrapolated to $\mathrm{kg} / \mathrm{hm}^{2}$.

\subsection{Statistical Analysis}

All data were represented as the mean \pm standard deviation (SE), and all analyses were carried out using SPSS 22 statistical software (IBM Corporation, Somers, NY, USA). 
Statistical differences between photosynthetic indexes (within each individual time point), and between antioxidant indexes (within each individual time point), and between nutrient indexes, and between the final yield treated by phthalanilic acid brassinolide, were determined using one-way analysis of variance (ANOVA), followed by Duncan's Multiple Range Test $(p<0.05)$.

\section{Results}

\subsection{Effect of PPA on Photosynthetic Properties of Cowpea}

The results of PPA on photosynthetic parameters in cowpea leaves are displayed in Figure 1. Four photosynthetic parameters had no obvious difference at the cowpea seedling period, among all treatments.

Compared with the blank control, at the full-bloom period, Pn increased by $15.31 \%$ at $133.3 \mathrm{mg} \cdot \mathrm{L}^{-1} \mathrm{PPA}$. At the early podding period, and Pn increased by $21.98-28.84 \%$ under three PPA treatments (Figure 1A). PPA treatments brought a significant decrease of $27.08-45.83 \%$ and $30.26-36.84 \%$ in Gs at the full-bloom and early podding period, respectively (Figure 1B). However, Ci (at the early podding period) was slightly increased by $6.45 \%$ and $9.47 \%$ at 133.3 and $200 \mathrm{mg} \cdot \mathrm{L}^{-1} \mathrm{PPA}$, respectively (Figure $1 \mathrm{C}$ ). $\mathrm{Tr}$ decreased significantly by $10.84-23.27 \%$ at the full-bloom and early podding period (except $133.3 \mathrm{mg} \cdot \mathrm{L}^{-1} \mathrm{PPA}$ ) under PPA treatments; however, no significant differences were observed at the seedling stage (Figure 1D). In addition, brassinolide treatment has the similar effect on photosynthetic properties of cowpea with PPA treatments.
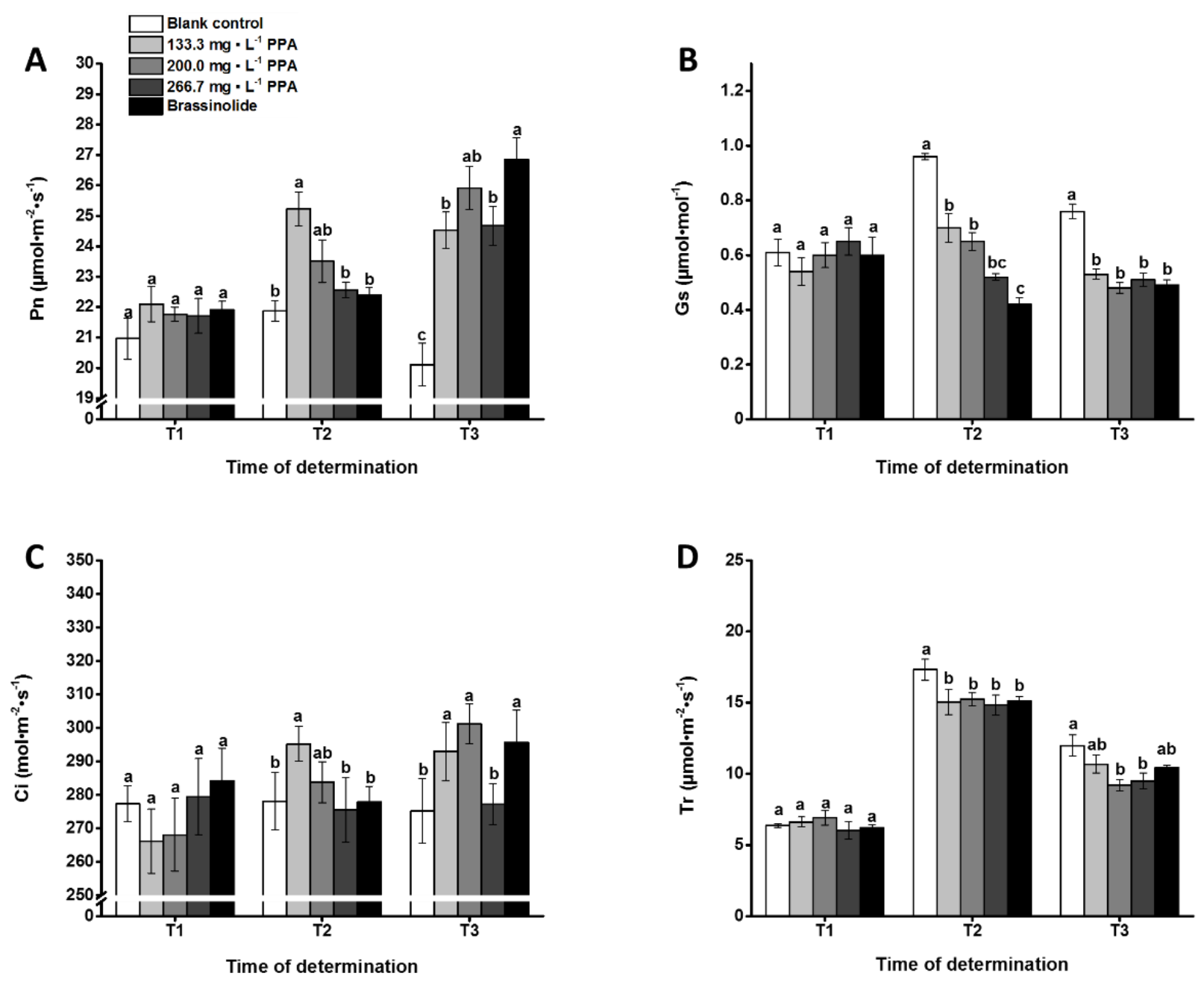

Figure 1. Cont. 


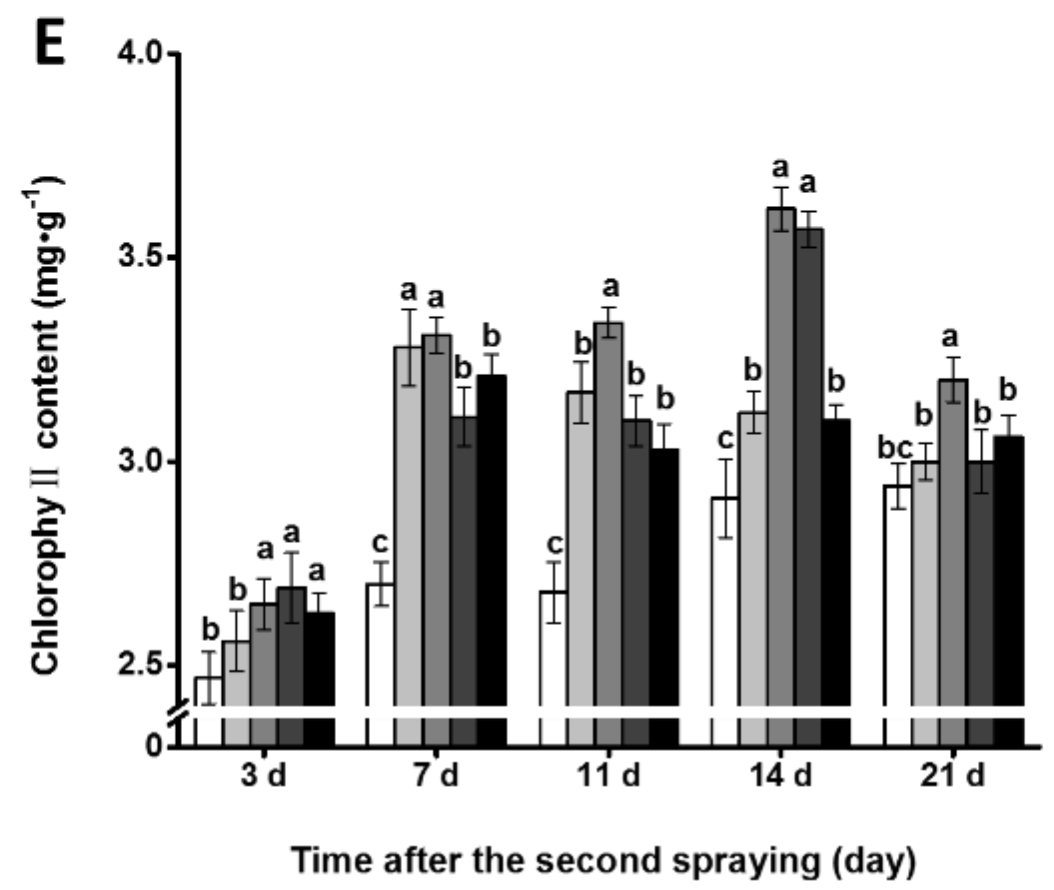

Figure 1. Effect of phthalanilic acid (PPA) on photosynthetic properties of cowpea leaves.T1, T2, and T3 indicate the stage of the seedlings, full-bloom, and early podding period, respectively. Chlorophyll content was detected after the second spraying. (A) represents the detected net photosynthetic rate (Pn); (B) represents the detected stomatal conductance (Gs); (C) represents the detected intercellular $\mathrm{CO}_{2}$ concentration (Ci); (D) represents the detected transpiration rate (Tr); (E) represents the detected chlorophyll content. The concentration of brassinolide applied to cowpea plants was $0.075 \mathrm{mg} \cdot \mathrm{L}^{-1}$. Pn, Gs, $\mathrm{Ci}$, and Tr represent photosynthetic rate, stomatal conductance, intercellular $\mathrm{CO}_{2}$ concentration, and transpiration rate, respectively. The data are represented as the means $( \pm \mathrm{SE})$ of three replications. Values with different lower-case letters are significantly different $(p<0.05)$ by Duncan's multiple range test at each same time point.

As can be seen from Figure 1E, different concentrations of PPA treatments increased the chlorophyll content of cowpea leaves. Compared with the blank control, PPA applications (except $133.3 \mathrm{mg} \cdot \mathrm{L}^{-1}$ ) and brassinolide significantly increased the chlorophyll content by about $11 \%$ on day 3 after the second spraying. On day 7, all the treatments presented a significant increase of $15.18-22.59 \%$. A statistical increase of 10.06-24.63\% was observed on days 11 and 14. However, on day 21 , only $200 \mathrm{mg} \cdot \mathrm{L}^{-1} \mathrm{PPA}$ showed a significant increase of $10.23 \%$.

\subsection{Effect of PPA on the Lipid Peroxidation and Electrolyte Leakage of Cowpea}

The results (Figure 2) show that electric conductivity significantly decreased by 22.66-62.18\% on days 11, and 21 post-PPA applications. However, no statistical differences were observed on days 3 and 7 (except $200 \mathrm{mg} \cdot \mathrm{L}^{-1} \mathrm{PPA}$ ).

MDA content statistically decreased by $14.41 \%, 18.25 \%, 13.65 \%$, and $20.20 \%$ on days 3 (133 $\left.\mathrm{mg} \cdot \mathrm{L}^{-1} \mathrm{PPA}\right), 11$ (200 $\left.\mathrm{mg} \cdot \mathrm{L}^{-1} \mathrm{PPA}\right), 14$ (200 $\left.\mathrm{mg} \cdot \mathrm{L}^{-1} \mathrm{PPA}\right)$, and 21 (brassinolide), respectively. However, the rest treatments were not significantly different from the control. 

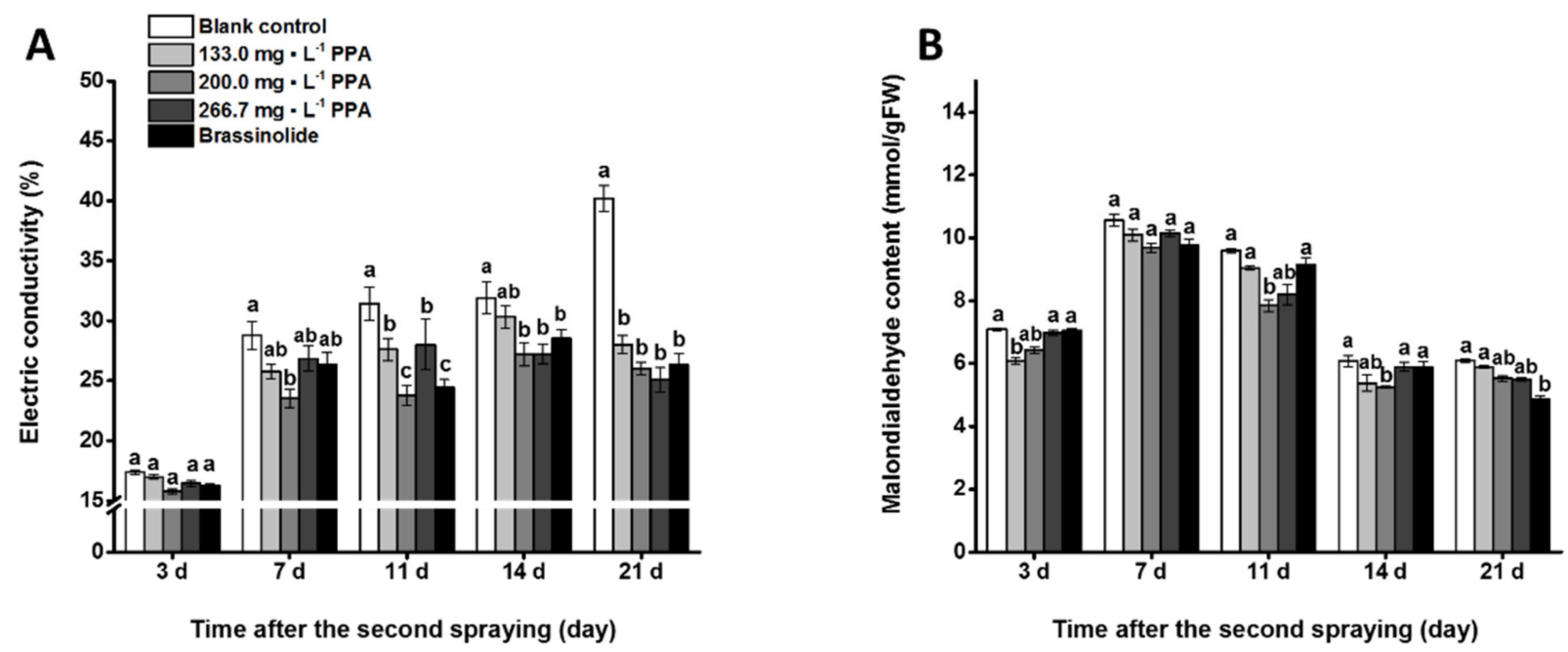

Figure 2. Effect of phthalanilic acid (PPA) on electric conductivity and malondialdehyde (MDA) content of cowpea leaves. The electric conductivity and MDA content were determined after the second spraying. (A) represents the detected electric conductivity and (B) represents the detected MDA content. The concentration of brassinolides applied to cowpea plants was $0.075 \mathrm{mg} \cdot \mathrm{L}^{-1}$. The data are represented as the means $( \pm \mathrm{SE})$ of three replications. Values with different lower-case letters are significantly different $(p<0.05)$ by Duncan's multiple range test at each same time point.

\subsection{Effect of PPA on Antioxidant Enzyme Activities in Cowpea}

The data of SOD, POD, and CAT activities in cowpea leaves are presented in Figure 3. Compared with the blank control, no significant differences were found on SOD from day 3 to day 21 after PPA and brassinolide treatments.

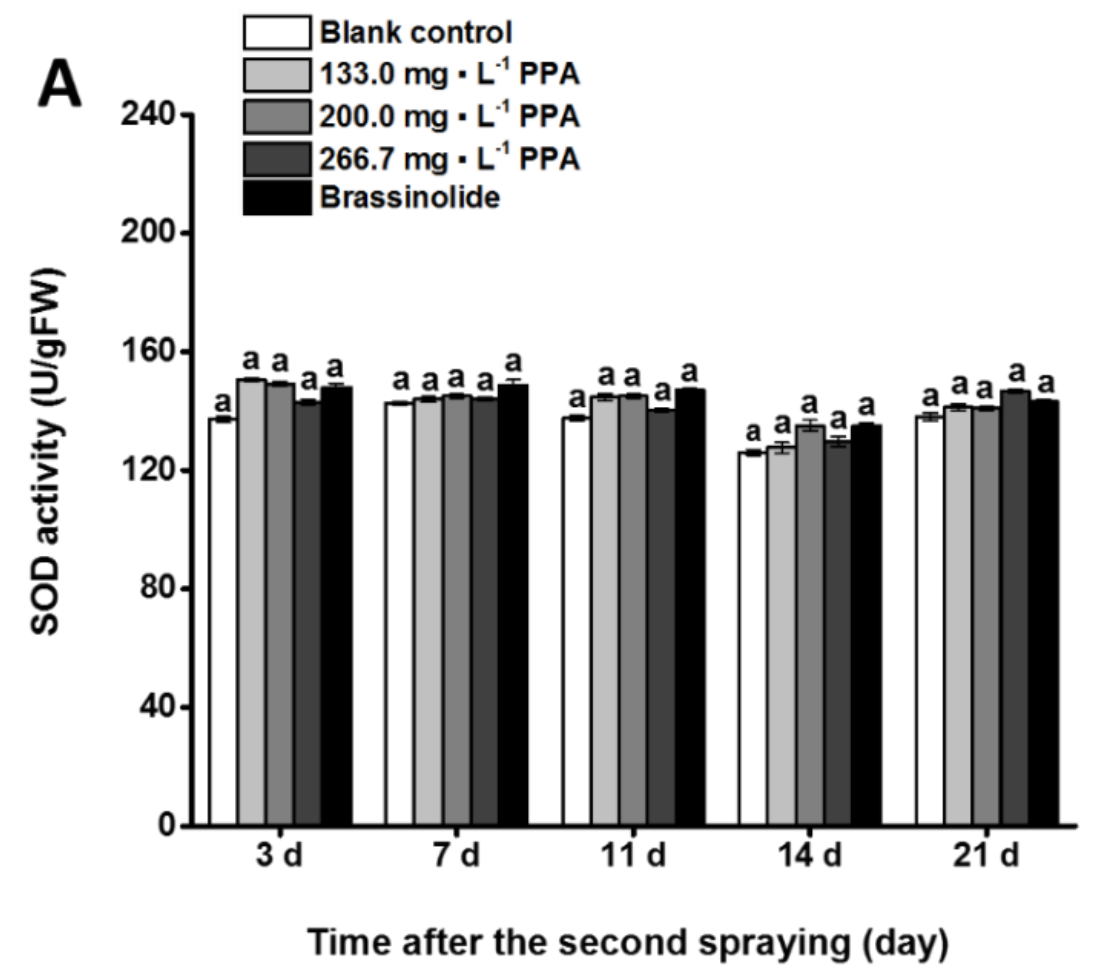

Figure 3. Cont. 

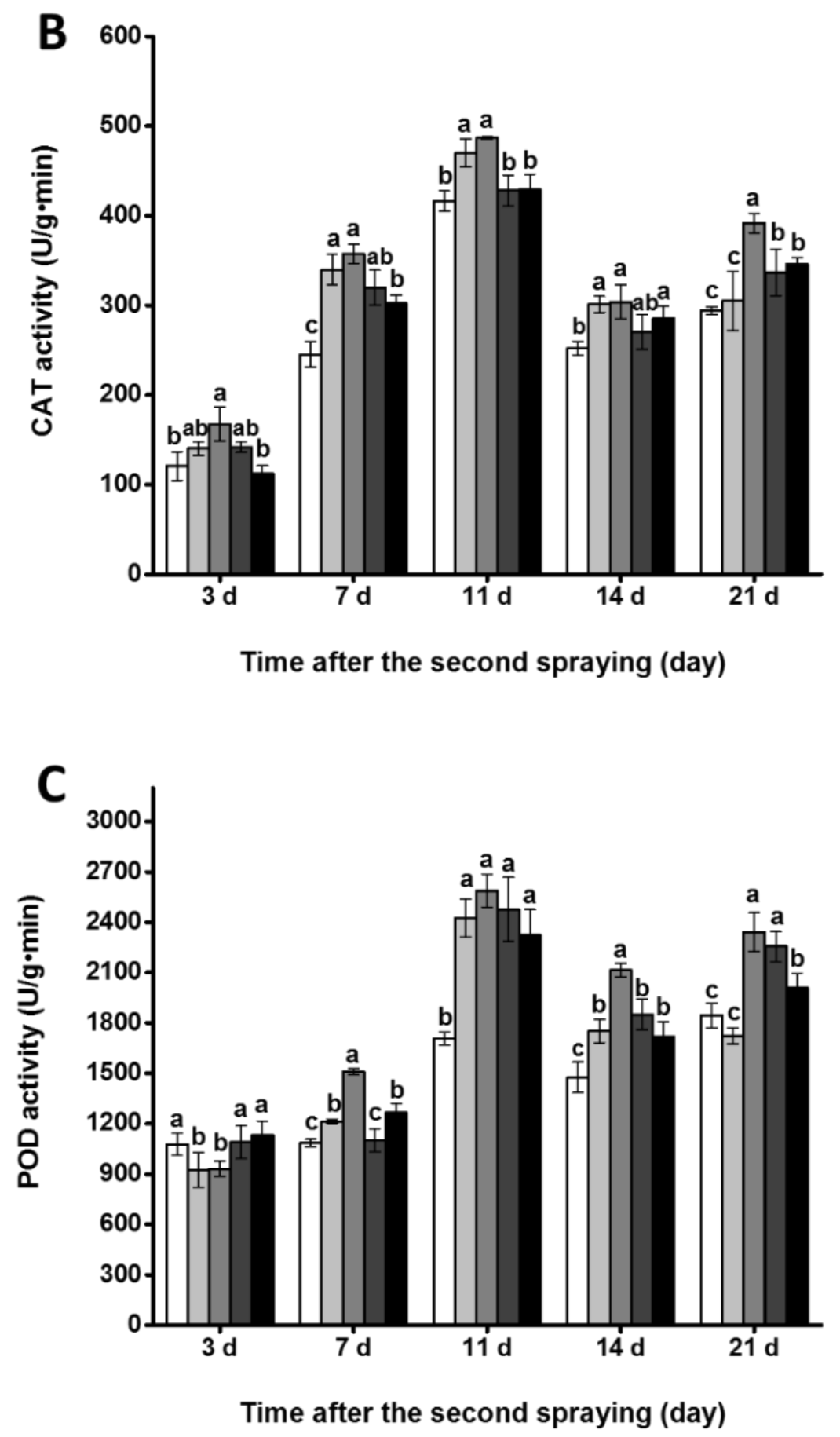

Figure 3. Effect of phthalanilic acid (PPA) on SOD, CAT, and POD activity in cowpea leaves. SOD, CAT, and POD activity were assayed after the second spraying. (A) represents the detected SOD activity; (B) represents the detected CAT activity; (C) represents the detected POD activity. The concentration of brassinolides applied to cowpea plants was $0.075 \mathrm{mg} \cdot \mathrm{L}^{-1}$. The data are represented as the means $( \pm \mathrm{SE})$ of three replications. Values with different lower-case letters are significantly different $(p<0.05)$ by Duncan's multiple range test at each same time point.

POD activity was significantly induced by an increment of 11.89-39.07\%, 36.15-51.62\%, 16.47-43.28\%, and 10.68-26.95\% on days 7 (except $266.7 \mathrm{mg} \cdot \mathrm{L}^{-1} \mathrm{PPA}$ ), 11, 14, and 21 (except $\left.133 \mathrm{mg} \cdot \mathrm{L}^{-1} \mathrm{PPA}\right)$, respectively.

CAT activity was significantly increased by PPA and brassinolide treatments on day 7 , and the increase rate was $23.34-38.67 \%$. A significant increase of $13.11-20.45 \%$ 
and $17.66-33.21 \%$ was observed on days 14 (except $266.7 \mathrm{mg} \cdot \mathrm{L}^{-1} \mathrm{PPA}$ ) and 21 (except $\left.133 \mathrm{mg} \cdot \mathrm{L}^{-1} \mathrm{PPA}\right)$, respectively.

\subsection{Effect of PPA on the Free Proline Content in Cowpea}

Free proline content in leaves of treated cowpea plants are elucidated in Figure 4. PPA and brassinolide increased the free proline content, and the increase rate was $16.25-80.42 \%$, $36.34-80.71 \%, 13.46-24.62 \%$, and $73.84-94.16 \%$ and on days $3,7,11$ (except $266.7 \mathrm{mg} \cdot \mathrm{L}^{-1}$ PPA and brassinolide), 14 (except $133 \mathrm{mg} \cdot \mathrm{L}^{-1} \mathrm{PPA}$ ), and 21, respectively. From day 3 to day 21 , proline content increased significantly by $200 \mathrm{mg} \cdot \mathrm{L}^{-1} \mathrm{PPA}$ treatment. The same effect was found in brassinolide treatment, but being lower than $200.0 \mathrm{mg} \cdot \mathrm{L}^{-1} \mathrm{PPA}$, except on days 14 and 21.

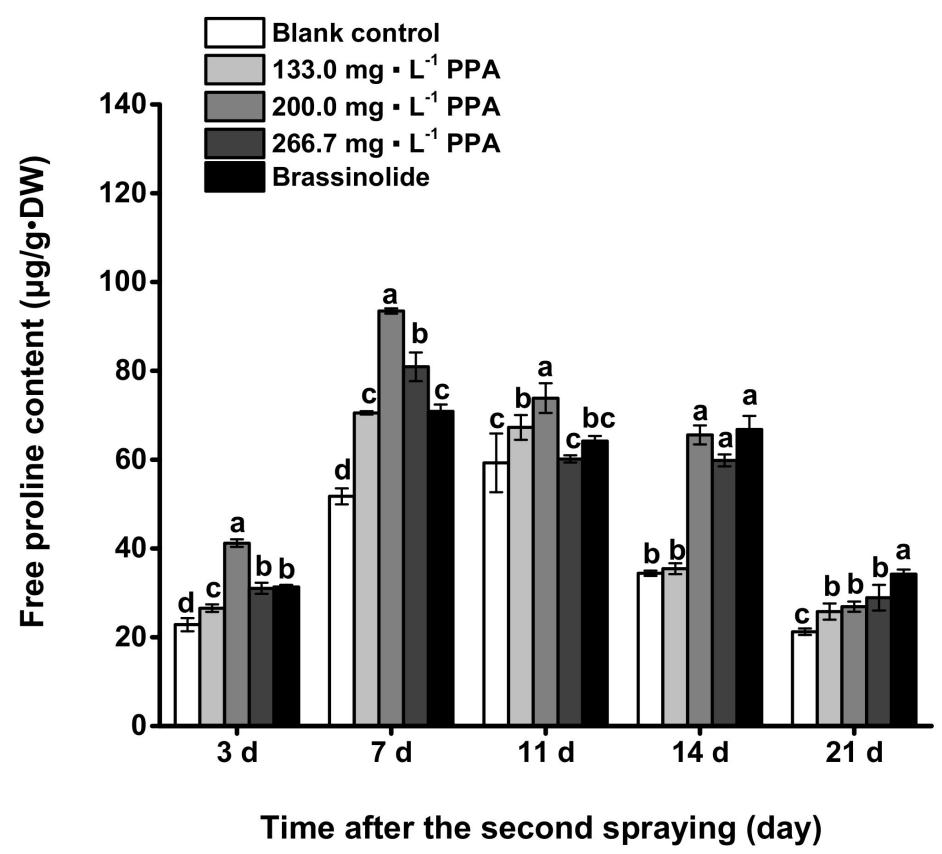

Figure 4. Effect of phthalanilic acid (PPA) on the free proline content of cowpea leaves. Free proline content was detected after the second spraying. The concentration of brassinolides applied to cowpea plants was $0.075 \mathrm{mg} \cdot \mathrm{L}^{-1}$. The data are represented as the means $( \pm \mathrm{SE})$ of three replications. Values with different lower-case letters are significantly different $(p<0.05)$ by Duncan's multiple range test at each same time point.

\subsection{Effect of PPA on the Quality of Cowpea}

The data in Table 1 indicate that PPA possessed positive effects on appearance quality of cowpea pods. At $200.0 \mathrm{mg} \cdot \mathrm{L}^{-1} \mathrm{PPA}$, the pod length increased by $8.67 \%$, while the single pod weight increased $15.94 \%$. The pod length and single pod weight of the brassinolide treatment were not significantly different from that of the blank controls.

Table 1. Effect of phthalanilic acid (PPA) on appearance quality of cowpea.

\begin{tabular}{ccccc}
\hline Treatment & $\begin{array}{c}\text { Concentration } \\
\left(\mathbf{m g} \cdot \mathbf{L}^{-\mathbf{1})}\right.\end{array}$ & Length $\mathbf{( c m )}$ & Width $\mathbf{( c m )}$ & $\begin{array}{c}\text { Single Pod } \\
\text { Weight } \mathbf{( g )}\end{array}$ \\
\hline Blank control & 0 & $50.62 \pm 3.24 \mathrm{~b}$ & $0.60 \pm 0.03 \mathrm{ab}$ & $10.10 \pm 0.67 \mathrm{~b}$ \\
& 133.3 & $54.00 \pm 1.91 \mathrm{a}$ & $0.61 \pm 0.05 \mathrm{a}$ & $10.89 \pm 1.72 \mathrm{ab}$ \\
Phthalanilic acid & 200.0 & $55.01 \pm 3.05 \mathrm{a}$ & $0.61 \pm 0.02 \mathrm{a}$ & $11.71 \pm 1.08 \mathrm{a}$ \\
& 266.7 & $51.96 \pm 1.83 \mathrm{ab}$ & $0.57 \pm 0.02 \mathrm{~b}$ & $10.30 \pm 1.26 \mathrm{~b}$ \\
Brassinolide & 0.075 & $50.95 \pm 2.07 \mathrm{~b}$ & $0.59 \pm 0.02 \mathrm{ab}$ & $10.55 \pm 0.46 \mathrm{ab}$ \\
\hline
\end{tabular}

Note: The data are represented as the means $( \pm$ SD) of three replications. Values in the same column with different letters are significantly different $(p<0.05)$ by Duncan's multiple range test. 
The nutrient qualities of cowpea were improved (Table 2). Vitamin C content was significantly increased by $200.0 \mathrm{mg} \cdot \mathrm{L}^{-1} \mathrm{PPA}$. In addition, PPA $\left(200.0 \mathrm{mg} \cdot \mathrm{L}^{-1}\right)$ and brassinolide displayed an increase of $18.75 \%$ and $30.10 \%$ on soluble protein content, but other treatments were not significantly different from the control. All the treatments promoted the content of soluble sugar except for $266.67 \mathrm{mg} \cdot \mathrm{L}^{-1} \mathrm{PPA}$.

Table 2. Effect of phthalanilic acid (PPA) on the nutrient quality of cowpea.

\begin{tabular}{ccccc}
\hline Treatment & $\begin{array}{c}\text { Concentration } \\
\left(\mathbf{m g} \cdot \mathbf{L}^{-\mathbf{1})}\right.\end{array}$ & $\begin{array}{c}\text { Vc Content } \\
\mathbf{( m g / 1 0 0} \mathbf{~ g} \cdot \mathbf{F W})\end{array}$ & $\begin{array}{c}\text { Soluble Protein } \\
\text { Content } \\
(\mathbf{m g} / \mathbf{g} \cdot \mathbf{F W})\end{array}$ & $\begin{array}{c}\text { Soluble Sugar } \\
\text { Content } \\
(\mathbf{m g} / \mathbf{g} \cdot \mathbf{F W})\end{array}$ \\
\hline Blank control & 0 & $13.04 \pm 0.50 \mathrm{~b}$ & $25.12 \pm 0.74 \mathrm{c}$ & $50.93 \pm 1.11 \mathrm{~b}$ \\
& 133.3 & $13.99 \pm 0.93 \mathrm{~b}$ & $26.09 \pm 0.88 \mathrm{c}$ & $53.92 \pm 2.23 \mathrm{a}$ \\
Phthalanilic acid & 200.0 & $16.85 \pm 0.55 \mathrm{a}$ & $29.83 \pm 0.68 \mathrm{~b}$ & $54.00 \pm 1.43 \mathrm{a}$ \\
Brassinolide & 266.7 & $14.31 \pm 0.46 \mathrm{~b}$ & $26.06 \pm 0.53 \mathrm{c}$ & $51.87 \pm 3.73 \mathrm{ab}$ \\
\hline
\end{tabular}

Note: The data are represented as the means $( \pm$ SD) of three replications. Values in the same column with different letters are significantly different $(p<0.05)$ by Duncan's multiple range test.

\subsection{Effect of PPA on the Podding Rate and Yield}

PPA $\left(200.0 \mathrm{mg} \cdot \mathrm{L}^{-1}\right)$ performed a statistical increment of $19.64 \%$ on the podding rate cowpea (Table 3); however, no significant difference was observed at 133 and $266.7 \mathrm{mg} \cdot \mathrm{L}^{-1}$ PPA. Similarly, $200.0 \mathrm{mg} \cdot \mathrm{L}^{-1}$ PPA significantly improved the yield, with the increase of $15.89 \%$, while brassinolide treatment possessed no significant difference from the blank control on these two indexes (Table 3).

Table 3. Effect of phthalanilic acid (PPA) on podding rate and yield of cowpea.

\begin{tabular}{|c|c|c|c|c|}
\hline Treatment & $\begin{array}{l}\text { Concentration } \\
\left(\mathrm{mg} \cdot \mathrm{L}^{-1}\right)\end{array}$ & $\begin{array}{l}\text { Podding Rate } \\
\qquad(\%)\end{array}$ & $\begin{array}{c}\text { Yield } \\
\left(\mathrm{kg} / \mathrm{hm}^{2}\right)\end{array}$ & $\begin{array}{c}\text { Yield Growth } \\
\text { Rate (\%) }\end{array}$ \\
\hline \multirow[t]{2}{*}{ Blank control } & 0 & $57.58 \pm 2.92 b$ & $2.14 \times 10^{4} \pm 1.24 \times 10^{3} \mathrm{~b}$ & - \\
\hline & 133.3 & $61.11 \pm 3.93 b$ & $2.37 \times 10^{4} \pm 1.60 \times 10^{3} \mathrm{ab}$ & 10.75 \\
\hline \multirow[t]{2}{*}{ Phthalanilic acid } & 200.0 & $68.89 \pm 3.85 \mathrm{a}$ & $2.48 \times 10^{4} \pm 1.34 \times 10^{3} \mathrm{a}$ & 15.89 \\
\hline & 266.7 & $63.33 \pm 4.77 \mathrm{ab}$ & $2.29 \times 10^{4} \pm 1.49 \times 10^{3} \mathrm{ab}$ & 7.01 \\
\hline Brassinolides & 0.075 & $61.11 \pm 5.09 \mathrm{~b}$ & $2.28 \times 10^{4} \pm 1.03 \times 10^{3} \mathrm{ab}$ & 6.54 \\
\hline
\end{tabular}

Note: The data are represented as the means $( \pm$ SD) of three replications. Values in the same column with different letters are significantly different $(\mathrm{P}<0.05)$ by Duncan's multiple range test.

\section{Discussion}

During the long-term evolution, plants have formed the adaptability to environment stresses by utilizing antioxidant and non-antioxidant systems to alleviate injury from overproduction of reactive oxygen species (ROS) [46-49]. The antioxidant enzyme system primarily consists of SOD, POD, and CAT [50]. Non-antioxidant enzyme systems contain flavonoids, total phenolics, free proline, etc., which act as an osmotic regulator of plant cytoplasm [51], or an effective ROS chelator [52,53]. Under their combined action, peroxidation products are quickly and effectively diminished, so as to make sure that plants normally grow under the adverse environment [54]. 5-aminolevulinic acid (ALA) defensed water-deficit stress by activating antioxidative and non-antioxidative defense systems in Brassica napus L. [55]. Additionally, the promotion in growth and metabolic activities induced by brassinolide treatment maintained the water potential and antioxidant enzyme activity of tissues reducing lipid peroxidation under drought conditions [21]. ABA and brassinolide significantly reduced the relative conductivity and malondialdehyde content of tall fescue leaves and increased the antioxidant enzyme activity and proline content of the leaves [22]. In addition, exogenous glycinebetaine application alleviated the adverse effects of salinity stress on maize plants by enhancing the photosynthesis capacity and the activity of some antioxidant enzymes [23].

In this research, the antioxidant and non-antioxidant enzyme systems in cowpea plants treated by PPA were investigated. The activity of the antioxidant enzyme system was 
enhanced in varying degrees, especially for POD. PPA treatments significantly increased POD activity, with an increase of $26.95-51.64 \%$. Similar results of elevated activity of antioxidant enzyme system were observed by PPA treatments in capsicum $[27,56]$. The increase in the activity of antioxidant enzymes enhances the ability of plants to scavenge active oxygen free radicals, which is beneficial to resist the surge of active oxygen in plants under stress conditions, keeping free radicals at a low level, thereby reducing damage to cells [57]. The promoted antioxidant enzyme system by PPA in cowpea would resist ROS stress and would further mitigate the oxidative damage.

When plants suffer from adversity stress, the destruction of cell membranes of leads to increased or even loss of membrane permeability, so that the electrolyte in the cell is exuded, which is manifested in the increase of relative electrical conductivity [58]. PostPPA treatments, the relative electrical conductivity was deceased, which would suggest that cells function well. In the meanwhile, changes in the content of osmotic adjustment substances (such as proline) are a strategy for plants to resist stresses [59]. Free proline content in cowpea was increased by $24.62-90.52 \%$ post-PPA applications, showing the potential of fighting against stresses. Additionally, MDA is one of the end products of membrane lipid peroxidation, and the MDA content is one of the representative indexes to assess the adversity to plant cells [60-63]. The decreased MDA content and relative electrical conductivity indicated the low degree of lipid peroxidation of the cell membrane, which would facilitate to prevent cytoplasm leakage and maintain the integrity and stability of the biofilm. The enhanced antioxidant enzyme system, together with improved nonantioxidant enzyme system by PPA, would potentially help cowpea plants to enhance the adaptability to environmental stresses.

The quality of cowpea mainly depends on the appearance and nutrition, including pod length, pod width, single pod weight, the content of soluble sugar, vitamin $C$ and phenols, and other important indicators $[64,65]$. In particular, the soluble protein is the most important nutrient substance of cowpea [65]. Significantly, both the appearance and internal quality of pods were improved post-PPA application. PPA markedly increased the pod length and single pod weight. Moreover, increased contents in vitamin C, soluble sugar, and soluble protein were also observed, suggesting that PPA, at $200.0 \mathrm{mg} \cdot \mathrm{L}^{-1}$, improved the nutrition content in cowpea. However, neither 133.3 nor $266.7 \mathrm{mg} \cdot \mathrm{L}^{-1}$ treatment displayed significant impact on internal quality. Interestingly, the similar effects of improving fruit quality also were found in capsicum post-PPA application [56]. As above, PPA improved the appearance and internal quality of cowpea by increasing the contents of $\mathrm{VC}$, soluble protein, and soluble sugar content in pods.

Effective improvement of the crop yield is the ultimate aim of using biostimulants. PPA application at $200.0 \mathrm{mg} \cdot \mathrm{L}^{-1}$ performed a significant yield-increasing effect on cowpea, with the increment of $15.89 \%$. Similarly, yield-increasing effects were also observed in sweet cherry, sour cherry, apple, and capsicum after PPA applications $[25,26,32]$. Photosynthesis is the basis of plant organic matter synthesis and energy storage, and transformation and enhanced photosynthesis is conducive to the accumulation of assimilation products in plants [64]. In this research, PPA applications increased the chlorophyll content and Pn, implying that PPA applications enhance photosynthesis and promote the transformation and assimilation of dry biomass in cowpea leaves. In addition, the foliar application of salicylic acid increased the integral biomass and Pn of corn plants, resulting in increased yield [66]. Moreover, PPA application induced cowpea leave partial stomata closure, resulting in Gs and $\mathrm{Tr}$ reduction, and $\mathrm{Ci}$ increasing. These physiological responses together affected the photosynthesis ability of cowpea leaves, which is similar with that of ABA and IAA treatments [66]. In addition, small molecules with biostimulatory effects improved resistance of crops to biological or non-biological stress to maintain normal growth and development, thus laying the foundation for the increase of production [15,67-69]. Analogously, antioxidant and non-antioxidant defenses were also elevated after PPA applications, which would improve the tolerance to stresses and would potentially contribute to increased yield. 
Taken together, the yield-increasing effect of PPA application on cowpea, on the one hand, might be related to the increased stress resistance and the promoted growth; on the other hand, might be related to the increase of the chlorophyll content and improved photosynthesis, resulting in increased accumulation of assimilation products in cowpea. The yield-increasing effect of PPA may be a comprehensive manifestation of multiple physiological effects. It should be pointed out that the yield-increasing mechanism is very complicated and requires further research.

\section{Conclusions}

The foliar spraying of PPA presents positive biostimulatory effects on cowpea plants of improving the photosynthetic properties and antioxidant and non-antioxidant defenses, leading to the improved fruit quality and the increased yield. This study indicates that PPA application with biostimulatory regulations is of important significance in modern cowpea production, and it is advisable to apply twice at $200.0 \mathrm{mg} \cdot \mathrm{L}^{-1}$ during the flowering period. Finally, it should be stated that the use of PPA is a feasible and sustainable practice to promote the yield and nutraceutical quality for horticultural crops.

Author Contributions: Conceptualization, T.M.; Data curation, Q.W.; Formal analysis, R.Z.; Investigation, Q.W. and R.Z.; Methodology, N.L.; Project administration, Z.M.; Resources, Z.M.; Writingreview \& editing, T.M. All authors have read and agreed to the published version of the manuscript.

Funding: This research was financially supported by Horizontal Cooperation Project (No. 20151001) and the cooperative partner was Shaanxi Sunger Road Bio-Science Co., Ltd., China.

Institutional Review Board Statement: Not applicable.

Informed Consent Statement: Not applicable.

Conflicts of Interest: This research was jointly completed by Provincial Center for Bio-Pesticide Engineering and Shaanxi Sunger Road Bio-Science Co., Ltd. (SSRB), and SSRB provided partial funding support and developed part field trials. According to the contract, both parties shall publish articles jointly, and the co-author listed in the article meets the requirements of the contract.

\section{References}

1. Campobenedetto, C.; Agliassa, C.; Mannino, G.; Vigliante, I.; Contartese, V.; Secchi, F.; Bertea, C.M. A Biostimulant Based on Seaweed (Ascophyllum nodosum and Laminaria digitata) and Yeast Extracts Mitigates Water Stress Effects on Tomato (Solanum lycopersicum L.). Agriculture 2021, 11, 557. [CrossRef]

2. Cristofano, F.; El-Nakhel, C.; Rouphael, Y. Biostimulant Substances for Sustainable Agriculture: Origin, Operating Mechanisms and Effects on Cucurbits, Leafy Greens, and Nightshade Vegetables Species. Biomolecules 2021, 11, 1103. [CrossRef]

3. Mrid, R.B.; Benmrid, B.; Hafsa, J.; Boukcim, H.; Yasri, A. Secondary metabolites as biostimulant and bioprotectant agents: A review. Sci. Total. Environ. 2021, 777, 146204. [CrossRef]

4. Agliassa, C.; Mannino, G.; Molino, D.; Cavalletto, S.; Contartese, V.; Bertea, C.M.; Secchi, F. A new protein hydrolysate-based biostimulant applied by fertigation promotes relief from drought stress in Capsicum annuum L. Plant Physiol. Bioch. 2021, 166, 1076-1086. [CrossRef] [PubMed]

5. Basile, B.; Rouphael, Y.; Colla, G.; Soppelsa, S.; Andreotti, C. Appraisal of emerging crop management opportunities in fruit trees, grapevines and berry crops facilitated by the application of biostimulants. Sci. Hortic. 2020, 267, 109330. [CrossRef]

6. Zhu, Y.; Jiang, X.; Zhang, J.; He, Y.; Zhu, X.; Zhou, X.; Gong, H.; Yin, J.; Liu, Y. Silicon confers cucumber resistance to salinity stress through regulation of proline and cytokinins. Plant Physiol. Biochem. 2020, 156, 209-220. [CrossRef]

7. Hassan, S.M.; Ashour, M.; Sakai, N.; Zhang, L.; Hassanien, H.A.; Gaber, A.; Ammarr, G.A.G. Impact of seaweed liquid extract biostimulant on growth, yield, and chemical composition of cucumber (Cucumis sativus). Agriculture 2021, 11, 320. [CrossRef]

8. Shukla, P.S.; Mantin, E.G.; Adil, M.; Bajpai, S.; Critchley, A.T.; Prithiviraj, B. Ascophyllum nodosum-Based Biostimulants: Sustainable Applications in Agriculture for the Stimulation of Plant Growth, Stress Tolerance, and Disease Management. Front. Plant Sci. 2019, 10, 655. [CrossRef]

9. Colla, G.; Hoagland, L.; Ruzzi, M.; Cardarelli, M.; Bonini, P.; Canaguier, R.; Rouphael, Y. Biostimulant Action of Protein Hydrolysates: Unraveling Their Effects on Plant Physiology and Microbiome. Front. Plant Sci. 2017, 8, 2202. [CrossRef] [PubMed]

10. Di Stasio, E.; Cirillo, V.; Raimondi, G.; Giordano, M.; Esposito, M.; Maggio, A. Osmo-Priming with Seaweed Extracts Enhances Yield of Salt-Stressed Tomato Plants. Agronomy 2020, 10, 1559. [CrossRef]

11. Stirk, W.A.; van Staden, J. Potential of phytohormones as a strategy to improve microalgae productivity for biotechnological applications. Biotechnol. Adv. 2020, 44, 107612. [CrossRef] [PubMed] 
12. Ali, O.; Ramsubhag, A.; Jayaraman, J. Biostimulant properties of seaweed extracts in plants: Implications towards sustainable crop production. Plants 2021, 10, 531. [CrossRef] [PubMed]

13. Shah, Z.H.; Rehman, H.M.; Akhtar, T.; Alsamadany, H.; Hamooh, B.T.; Mujtaba, T.; Daur, I.; Al Zahrani, Y.; Alzahrani, H.A.S.; Ali, S.; et al. Humic Substances: Determining Potential Molecular Regulatory Processes in Plants. Front. Plant Sci. $2018,9,263$. [CrossRef] [PubMed]

14. Ahmed, F.; Baloch, D.M.; Sadiq, S.A.; Ahmed, S.S.; Hanan, A.; Taran, S.A.; Ahmed, N.; Hassan, M.J. Plant growth regulators induced drought tolerance in sunflower (Helianthus annuus L.) hybrids. J. Anim. Plant. Sci. 2014, 24, 886-890.

15. Fariduddin, Q.; Zaid, A.; Mohammad, F. Plant growth regulators and salt stress: Mechanism of tolerance trade-off. In Salt Stress, Microbes, and Plant Interactions: Causes and Solution; Akhtar, M., Ed.; Springer: Singapore, 2019.

16. Ilias, I.F.; Maksimović, V.M.; Giannakoula, A.E.; Maksimović, J.J.D.; Živanović, B.D. The effects of plant growth regulators on growth, yield, and phenolic profile of lentil plants. Food Compos. Anal. 2012, 28, 46-53.

17. Mao, L.; Zhang, L.; Zhao, X.; Liu, S.; Werf, W.V.D.; Zhang, S.; Li, Z. Crop growth, light utilization and yield of relay intercropped cotton as affected by plant density and a plant growth regulator. Field Crop. Res. 2014, 155, 67-76. [CrossRef]

18. Zaid, A.; Mohammad, F.; Fariduddin, Q. Plant growth regulators improve growth, photosynthesis, mineral nutrient and antioxidant system under cadmium stress in menthol mint (Mentha arvensis L.). Physiol. Mol. Biol. Plants 2020, 26, 25-39. [CrossRef]

19. Li, X.; Zhong, Q.; Li, Y.; Li, G.; Ding, Y.; Wang, S.; Chen, L. Triacontanol reduces transplanting shock in machine-transplanted rice by improving the growth and antioxidant systems. Front. Plant Sci. 2016, 7, 872. [CrossRef]

20. Asadi Karam, E.; Keramat, B.; Asrar, Z.; Mozafari, H. Study of interaction effect between triacontanol and nitric oxide on alleviating of oxidative stress arsenic toxicity in coriander seedlings. J. Plant Interact. 2017, 12, 14-20. [CrossRef]

21. Anjum, S.A.; Wang, L.C.; Farooq, M.; Hussain, M.; Zou, C.M. Brassinolide application improves the drought tolerance in maize through modulation of enzymatic antioxidants and leaf gas exchange. J. Agron. Crop Sci. 2011, 197, 177-185. [CrossRef]

22. Chen, Z.F.; Wang, Z.; Yang, Y.G.; Li, M.; Xu, B.C. Abscisic acid and brassinolide combined application synergistically enhances drought tolerance and photosynthesis of tall fescue under water stress. Sci. Hortic-Amst. 2018, 228, 1-9. [CrossRef]

23. Nawaz, K.; Ashraf, M. Exogenous application of glycinebetaine modulates activities of antioxidants in maize plants subjected to salt stress. J. Agron. Crop Sci. 2010, 196, 28-37. [CrossRef]

24. Zhao, H.; Xu, J.; Dong, F.; Liu, X.; Wu, Y.; Zhang, J.; Zheng, Y. Determination of phthalanilic acid residue in bean, fruits and vegetables using a modified quechers method and ultra-performance liquid chromatography/tandem mass spectrometry. Anal. Methods 2014, 4596, 4336-4342. [CrossRef]

25. Racskó, J.; Holb, I.; Szabo, Z.; Thurzo, S.; Dren, G.; Nyeki, J. Effect of auxin-synergistic preparation (Nevirol 60 WP) on flowering date and yield of sour-cherry and European plum fruits in Hungary. Acta Hortic. 2006, 727, 279-282. [CrossRef]

26. Racskó, J.; Szabo, Z.; Nyeki, J. Direct and indirect effects of N-phenyl-phthalamic acid and fertilization on fruit setting and fruit quality parameters of apple (Malus domestica Borkh.). Acta Hortic. 2006, 3, 209-216. [CrossRef]

27. Zhang, O.; Ma, Q.; Liu, N.; Ma, Z.Q.; Zhang, X. Effect of phthalanilic acid on stress resistance and yield of pepper. Chin. J. Pestic. Sci. 2017, 19, 449-456.

28. Li, L.F.; Zhou, D.W.; Wang, Y.S. Study on the effect of phthalanilic acid on promoting the flower bud formation of Hongfushi apple. Northwest Horticult. 2019, 11, 54-55.

29. Khadivikhub, A.; Nosrati, Z. Study of N-phenyl-phthalamic acid effects on fruit setting and fruit quality of sweet, sour and duke cherries. Acta Agr. Serb. 2013, 17, 3-9.

30. Racskó, J.; Lakatos, L.; Kövics, G.J. Effect of N-phenilphtalanic acid (NEVIROL 60 WP) on quantitative and qualitative parameters of some horticultural plants. In Proceedings of the International Plant Protection Symposium at Debrecen University and Trans-Tisza Plant Protection Forum, Debrecen, Hungary, 15-16 October 2003; pp. 216-224.

31. Albuquerque, J.D.A.A.D.; Oliva, L.S.D.C.; Alves, J.M.A.; Uchôa, S.C.P.; Melo, D.A.D. Cultivation of cassava and cowpea in intercropping systems held in Roraima's savannah, Brazil. Rev. Cienc. Agron. 2015, 46, 93-99. [CrossRef]

32. Karapanos, I.; Papandreou, A.; Skouloudi, M.; Makrogianni, D.; Fernández, J.A.; Rosa, E. Cowpea fresh pods: A new legume for the market assessment of their quality and dietary characteristics of 37 cowpea accessions grown in southern Europe. J. Sci. Food Agr. 2017, 97, 4343. [CrossRef]

33. Bhattarai, G.; Shi, A.; Qin, J.; Weng, Y.; Morris, J.B.; Pinnow, D.L.; Dong, L. Association analysis of cowpea mosaic virus (CPMV) resistance in the USDA cowpea germplasm collection. Euphytica 2017, 213, 230. [CrossRef]

34. Guzzetti, L.; Fiorini, A.; Panzeri, D.; Tommasi, N.; Grassi, F.; Taskin, E.; Misci, C.; Puglisi, E.; Tabaglio, V.; Galimberti, A.; et al. Sustainability perspectives of Vigna unguiculata L. Walp. cultivation under no tillage and water stress conditions. Plants 2020, 9 , 48. [CrossRef]

35. Elsaeid, H.M.; Abouhussein, S.D.; Eltohamy, W.A. Growth characters, yield and endogenous hormones of cowpea plants in response to IAA application. Res. J. Agr. Biol. Sci. 2010, 6, 27-31.

36. Patel, H.D.; Patel, H.C.; Sitapara, H.H.; Nayee, D.D. Influence of plant growth regulators on growth and green pod yield of cowpea (Vigna unguiculata L.) cv. ANAND VEG. COWPEA-1. Asian J. Hortic. 2011, 6, 491-495.

37. Yang, X.; Li, G.; Luo, W.; Chen, L.; Li, S.; Cao, M.; Zhang, X. Quantifying the relationship between leaf nitrogen content and growth dynamics and yield of muskmelon grown in plastic greenhouse. Hortscience 2015, 50, 1677-1687. [CrossRef]

38. Arnon, D.I. Copper enzymes in isolated chloroplasts polyphenoloxidase in beta vulgaris. Plant Physiol. 1949, 24, 1-15. [CrossRef] 
39. Ekmekci, Y.; Terzioglu, S. Effects of oxidative stress induced by paraquat on wild and cultivated wheats. Pestic. Biochem. Phys. 2005, 83, 69-81. [CrossRef]

40. Zhao, H.; Dai, T.; Jing, Q.; Jiang, D.; Cao, W. Leaf senescence and grain filling affected by post-anthesis high temperatures in two different wheat cultivars. Plant Growth Regul. 2007, 51, 149-158. [CrossRef]

41. Bates, L.S.; Waldren, R.P.; Teare, I.D. Rapid determination of free proline for water-stress studies. Plant Soil 1973, 39, $205-207$. [CrossRef]

42. Xiong, X.; Yao, M.; Fu, L.; Ma, Z.Q.; Zhang, X. The botanical pesticide derived from sophora flavescens, for controlling insect pests can also improve growth and development of tomato plants. Ind. Crop. Prod. 2016, 92, 13-18. [CrossRef]

43. Zhang, Y.J.; Zhang, X.; Chen, C.J.; Zhou, M.G.; Wang, H.C. Effects of fungicides js399-19, azoxystrobin, tebuconazloe, and carbendazim on the physiological and biochemical indices and grain yield of winter wheat. Pestic. Biochem. Phys. 2010, 98, 151-157. [CrossRef]

44. Masuthi, D.A.; Vyakaranahal, B.S.; Deshpande, V.K. Influence of pelleting with micronutrients and botanical on growth, seed yield and quality of vegetable cowpea. Karnataka J. Agr. Sci. 2010, 22, 35-38.

45. Nakano, H.; Hirata, K.; Ohnishi, M. Effects of planting density on light interception and on the growth and yield of soybean (agronomy). Jpn. J. Crop Sci. 2004, 73, 175-180. [CrossRef]

46. Fariduddin, Q.; Yusuf, M.; Ahmad, I.; Ahmad, A. Brassinosteroids and their role in response of plants to abiotic stresses. Biol. Plant. 2013, 58, 9-17. [CrossRef]

47. Wani, W.; Masoodi, K.Z.; Zaid, A.; Wani, S.H.; Shah, F.; Meena, V.S.; Mosa, K.A. Engineering plants for heavy metal stress tolerance. Rend Lincei-Sci. Fis. 2018, 29, 709-723. [CrossRef]

48. Wani, S.H.; Tripathi, P.; Zaid, A.; Challa, G.S.; Kumar, A.; Kumar, V.; Bhatt, M. Transcriptional regulation of osmotic stress tolerance in wheat (Triticum aestivum L.). Plant Mol. Biol. 2018, 97, 469-487. [CrossRef]

49. Zaid, A.; Wani, S.H. Reactive oxygen species generation, scavenging and signaling in plant defense responses. In Bioactive Molecules in Plant Defense; Jogaiah, S., Abdelrahman, M., Eds.; Springer: Cham, Switzerland, 2019.

50. Shah, K.; Nahakpam, S. Heat exposure alters the expression of SOD, POD, APX and CAT isozymes and mitigates low cadmium toxicity in seedlings of sensitive and tolerant rice cultivars. Plant Physiol. Bioch. 2012, 57, 106-113. [CrossRef] [PubMed]

51. Ghoulam, C.; Foursy, A.; Fares, K. Effects of salt stress on growth, inorganic ions and proline accumulation in relation to osmotic adjustment in five sugar beet cultivars. Environ. Exp. Bot. 2002, 47,39-50. [CrossRef]

52. Anjum, F.; Rishi, V.; Ahmad, F. Compatibility of osmolytes with gibbs energy of stabilization of proteins. BBA Protein Struct. Mol. Enzymol. 2000, 1476, 75-84. [CrossRef]

53. Hare, P.D.; Cress, W.A. Metabolic implications of stress-induced proline accumulation in plants. Plant Growth Regul. 1997, 21, 79-102. [CrossRef]

54. Almeselmani, M.; Deshmukh, P.S.; Sairam, R.K.; Kushwaha, S.R.; Singh, T.P. Protective role of antioxidant enzymes under high temperature stress. Plant Sci. 2006, 171, 382-388. [CrossRef]

55. Liu, D.; Pei, Z.F.; Naeem, M.S.; Ming, D.F.; Liu, H.B.; Khan, F. 5-aminolevulinic acid activates antioxidative defence system and seedling growth in Brassica napus L. under water-deficit stress. J. Agron. Crop Sci. 2011, 197, 284-295. [CrossRef]

56. Wu, Q.; Zhang, R.; Li, Z.; Ma, Z.Q.; Zhang, X. Effect of phthalanilic acid on the endogenous hormone content and fruit quality and yield of peppers. Chin. J. Pestic. Sci. 2018, 20, 625-633.

57. Schutzendubel, A.; Polle, A. Plant responses to abiotic stresses: Heavy metal-induced oxidative stress and protection by mycorrhization. J. Exp. Bot. 2002, 53, 1351-1365. [CrossRef]

58. Huang, S.; Li, X.H.; Tao, X.Y.; Lin, D.; Mao, L.C. Study on the effect of anti damage in strawberry with the anti-vibration package. Sci. Techol. Food Ind. 2015, 36, 272-275.

59. Al-Yasi, H.; Attia, H.; Alamer, K.; Hassan, F.; Hessini, K. Impact of drought on growth, photosynthesis, osmotic adjustment, and cell wall elasticity in damask rose. Plant Physiol. Bioch. 2020, 150, 133-139. [CrossRef]

60. Xu, F.; Liu, S.; Xiao, Z.; Fu, L. Effect of ultrasonic treatment combined with 1-methylcyclopropene (1-MCP) on storage quality and ethylene receptors gene expression in harvested apple fruit. J. Food Biochem. 2019, 43, e12967. [CrossRef] [PubMed]

61. Xu, F.; Lu, F.; Xiao, Z.; Li, Z. Influence of drop shock on physiological responses and genes expression of apple fruit. Food Chem. 2020, 303, 125424. [CrossRef]

62. Lu, F.; Xu, F.; Li, Z.; Liu, Y.; Wang, J.; Zhang, L. Effect of vibration on storage quality and ethylene biosynthesis-related enzyme genes expression in harvested apple fruit. Sci. Hortic-Amst. 2019, 249, 1-6. [CrossRef]

63. Xu, F.X.; Liu, S.Y. Control of postharvest quality in blueberry fruit by combined 1-methylcyclopropene (1-MCP) and UV-C irradiation. Food Bioproc. Tech. 2017, 10, 1695-1703. [CrossRef]

64. Zhan, Y.F.; Dang, X.M.; Qi, Z.Q.; He, H.; Yang, Y. Main agronomic and quality characters of asparagus bean (Vigna unguiculata ssp. sesquipedalis) germplasms. J. South. Agr. 2015, 46, 2006-2010.

65. Rao, L.B.; Chen, X.Z.; Chen, X.X.; Feng, G.; Zheng, J.H. Identification and comprehensive assessment on long cowpea germplasm resources. J. Zhejiang Agr. Sci. 2009, 1, 39-41.

66. Zhou, X.M.; Mackenzie, A.F.; Madramootoo, C.A.; Smith, D.L. Effects of stem-injected plant growth regulators, with or without sucrose, on grain production, biomass and photosynthetic activity of field-grown corn plants. J. Agron. Crop Sci. 2010, 183, 103-110. [CrossRef] 
67. Barányiová, I.; Klem, K. Effect of application of growth regulators on the physiological and yield parameters of winter wheat under water deficit. Plant Soil Environ. 2016, 62, 114-120. [CrossRef]

68. Fahad, S.; Hussain, S.; Saud, S.; Hassan, S.; Ihsan, Z.; Alghabari, F. Exogenously applied plant growth regulators enhance the morpho-physiological growth and yield of rice under high temperature. Front. Plant Sci. 2016, 7, 1250. [CrossRef] [PubMed]

69. Robinson, D.; Orson, J. Plant growth regulators: Their effect on yield of winter wheat in a very dry spring and in the absence of lodging. Ann. Appl. Biol. 2012, 40, 91-94. 